\title{
Solution Properties of Marine Humic Acid. II.
}

\section{Aggregate Formation and Effects of Metal Ions on Solution Properties}

\author{
Noriko ShinOzUKa, Osamu Shinj, and Shigeo Hayano \\ Institute of Industrial Science, University of Tokyo \\ (22-1, Roppongi 7-chome, Minato-ku, Tokyo)
}

\begin{abstract}
The interfacial tension and the conductivity of humic acid solutions were measured and the ag= gregate formation was suggested. The concentration at which aggregation begins is in good accords ance with that determined by other methods.

The effect of metal cations on the conductivity, viscosity, interfacial tension, and potentiometric titration of humic acid solutions was also examined. The added metal cations form complexes with marine humic acid, the order of complexing ability of metal cations is as follows :$$
\mathrm{Na}^{+} ; \mathrm{K}^{+}<\mathrm{Mg}^{2+}<\mathrm{Ca}^{2+}<\mathrm{Ba}^{2+}<\mathrm{Cu}^{2+}
$$

The metal ions are thought to be mainly bound to the carboxyl ions of the humic acid. No sub= stantial difference was observed between marine humic acid and commercially obtained Aldrich humic acid in the effect of cations on solution properties.

The marine humic acid samples fractionated by molecular weight were used to study the molecs ular size effect on the solution properties. It is confirmed that the smaller molecule shows the lower humification degree and the higher acidity.
\end{abstract}

\section{Introduction}

In the previous paper $^{1)}$, the polyelectrolytic properties of the marine humic acid was studied by the viscosity measurement. The conclusions are that the humic acids show typical polyelec= trolytic properties and their conformation in the solution depends on $\mathrm{pH}$, aging time, concentra $=$ tion, and the amount of added salt. The ag= gregate formation is suggested and the critical concentration for aggregation from the viscosity measurements is in good agreement with that determined by the surface tension measure $=$ ments ${ }^{2}$.

This paper describes the conductometric and interfacial tension studies with and without metal ions. The knowledge of the effect of metal cations on the solution properties of humic acid would be necessary to elucidate the state of humic substances in marine water. The frac $=$ tionated samples by ultrafiltration are examined and the molecular size effect on the solution properties is discussed.

\section{Experimental}

Samples of humic acids were prepared by the same method as in the previous paper"). Con = ductivity measurements were carried out with a digital conductometer (Toa Dempa Co. Ltd., CM-15A) in nitrogen atmosphere at $25 \pm 0.1^{\circ} \mathrm{C}$. Interfacial tensions were determined by the fol= lowing procedure; Into a weighing bottle con= taining a $10 \mathrm{ml}$ test solution, $6 \mathrm{ml}$ of $n$-hexane saturated with water was poured thoroughly. The bottle was allowed to stand for $3 \sim 4 \mathrm{~d}$ at $25 \pm 0.5^{\circ} \mathrm{C}$, then the interfacial tension was measured by a Wilhelmy type surface tensio $=$ meter (Shimadzu Seisakusho Ltd., ST-1). The temperature was controlled at $25 \pm 0.5^{\circ} \mathrm{C}$.

The ultrafiltration was carried out with an ultrafiltration apparatus (Bioengineering Co., $\mathrm{MC}-2$ ) with membranes (Amicon Co.) of XM300 (cutoff molecular weight, c.m.w., 300,000), XM-100 A (c.m.w. 100,000) and PM-10 (c.m.w., 100,000 ). A solution of $1 \mathrm{~g}$ marine humic acid dissolved into $200 \mathrm{ml}$ of $0.05 \mathrm{~N} \mathrm{KOH}$ and al $=$ lowed to stand for 1 month at $25^{\circ} \mathrm{C}$ was used 
for ultrafiltration.

Viscosity was measured by the same proce $=$ dure as described before.

All chemicals used except humic acids are of reagent grade.

\section{Results and Discussion}

\subsection{Interfacial tension between aqueous solution and $n$-hexane}

The interfacial tension between the aqueous potassium marine humate and $n$-hexane was plotted in Fig.-1. These data were obtained after the equilibration at the interface was at $=$ tained. The interfacial tension of marine humate diminishes from $50 \mathrm{dyn} / \mathrm{cm}$ to $10 \mathrm{dyn} / \mathrm{cm}$, which shows the relatively high surface activity of the marine humate. An inflection point appeared at about $0.1 \%$ for the solution without salt, which is probably due to the aggregate forma= tion. With $\mathrm{KCl}$ addition, the inflection point shifts to the lower concentration like salt effect on ionic surfactant solutions.

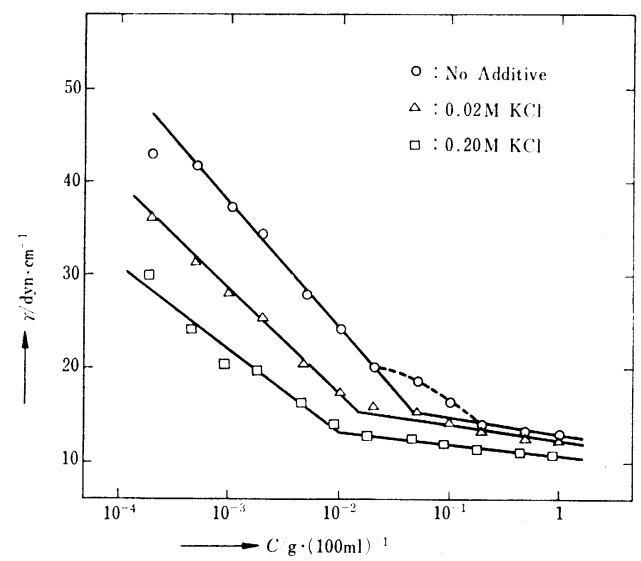

Fig.-1 Concentration dependence of interfacial tension (marine humic acid)

The interfacial tension of Aldrich humic acid (Fig.-2) is a little higher than the marine umate and inflection points also appeared when $\mathrm{KCl}$ was added. Without salt, it does not exhibit apparent bending points; these results ndicate that the aggregation may proceed not ike micellization but like step-by-step ${ }^{3)}$.

\section{$3 \cdot 2$ Conductometric behavior}

The conductivity of neutralized humic acid solutions are shown in Fig.-3. A bending soint is observed on the curve of the marine

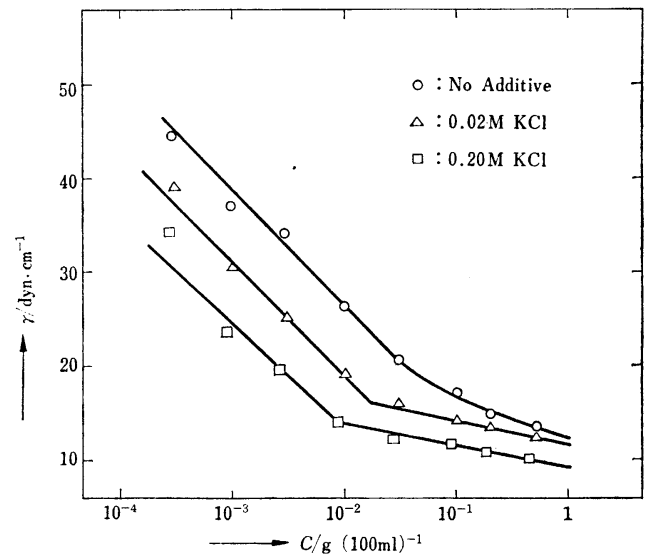

Fig.-2 Concentration dependence of interfacial tension (Aldrich humic acid)

humic acid at about $0.1 \%$. The solution of low neutralization degree shows a slight bend ing point at about $0.05 \mathrm{~g} / 100 \mathrm{ml}$. Aldrich hus mic acid curves can not be represented as a straight line, suggesting that the aggregation may occur step-by-step. These results are in good accordance with those from interfacial tension measurements.

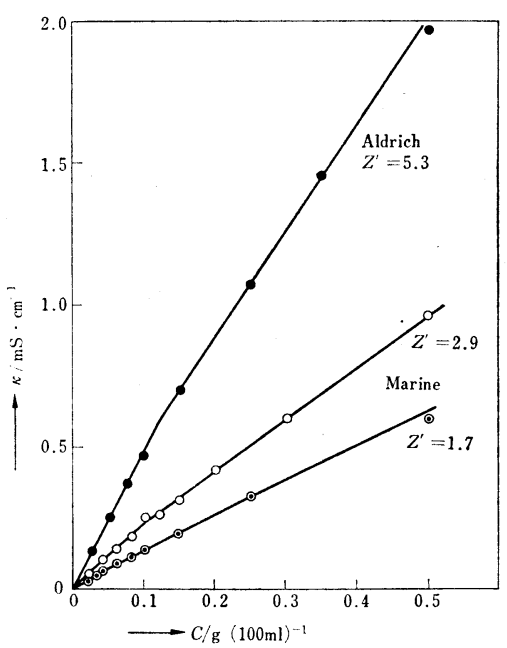

Fig.-3 Concentration dependence of conductivity.

\subsection{The Effect of Metal Ions on Solution Properties}

\section{$3 \cdot 3 \cdot 1$ Conductivity}

When a metal chloride is added to an aliquot of water, the conductivity of the solution rises linearly with the salt concentration. In the case that metal chloride is added to potassium 


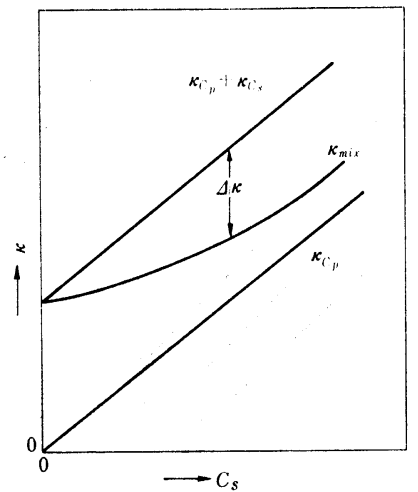

Fig.-4 Effect of complex formation on conductivity.

humate solution, the conductivity increases ace cording to the salt concentration if they do not interact. Actually humic acids form complexes with metal ions and the conductivity of the system decreases with the degree of complex formation. The relation is shown in Fig. -4 .

The concentration of metal cation coordinated to humic acid is evaluated as follows :

Suppose the complex formation is described,

$$
n\left(\mathrm{COO}^{-}\right)+\mathrm{M}^{n+} \rightarrow\left(-\mathrm{COO}^{-}\right)_{n} \mathrm{M}
$$

The decrease of the metal chloride concentra $=$ tion by chelation $\left(\Delta C_{s}\right)$ is

$$
\Delta C_{s}=\frac{\kappa_{C_{p}}+\kappa_{c_{s}}-\kappa_{\mathrm{mix}}}{\lambda \mathrm{M}^{n+}+\lambda \mathrm{COO}^{-}}
$$

where $\lambda_{\mathrm{M}^{+}}$, $\lambda \mathrm{COO}^{-}$are ionic conductivity of $\mathrm{M}^{n+}$ and $\mathrm{COO}^{-}$respectively, $\kappa_{c_{p}}, \kappa_{c_{s}}, \kappa_{\text {mix }}$ are con= ductivity of potassium humate, the salt and the mixed solution respectively. The value of $i \mathrm{COO}$ was determined from Fig. $-\mathbf{5}$ to extrapolate to $C_{p} \rightarrow 0$ then subtract $\lambda_{\mathrm{K}^{+}}$from the obtained value. When the equivalent conductivity of a solution is $A$, the ionic conductivity is,

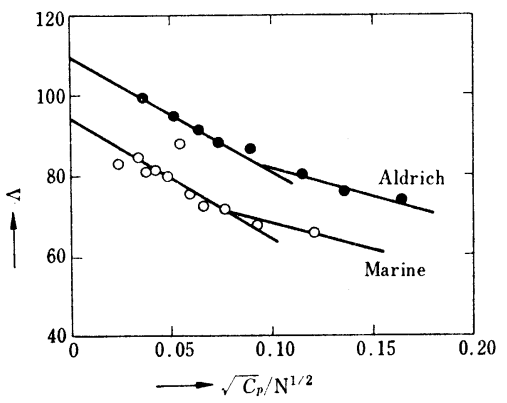

Fig.-5 Equivalent conductivity change with concentration.

$$
\lambda \mathrm{COO}^{-}=\frac{A}{A^{\circ}} \lambda^{\circ} \mathrm{COO}^{-}
$$

$i \mathrm{M}^{n+}$ is determined by the same procedure.

Fig. -6 illustrates the relation between $\Delta C_{s}$ and $C_{s}$, together with adsorbed $\mathrm{M}^{n+}$ in meq/g of humic acid. From the figure it is seen that the added $\mathrm{H}^{+}$forms complex with humic acid and the concentration of adsorption increases linearly. This results is in good accordance with that of $\mathrm{pH}$ titration. In the large $C_{s}$ range, complex formation reaches to the saturation but the value seems to be low compared to the amount of charge of the marine humic acid $(=2.9 \mathrm{meq} / \mathrm{g})$. The presence of a strong acid, which was already pointed out, may cause the lower saturation value than expected. This is also consistent with the observation by $\mathrm{Piccolo}^{7}$ ) that not all $\mathrm{COOH}$ groups of humic acid bound metal ions.
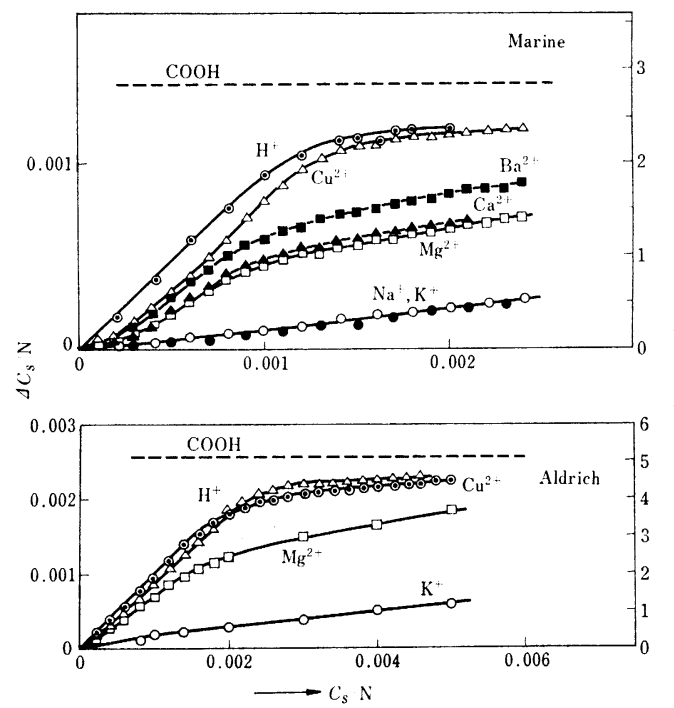

Fig.-6 Metal ion absorption on humic acid (humic acid concentration; $0.05 \mathrm{~g} /$ $100 \mathrm{ml}$, fully neutralized).

Potassium and sodium ions scarcely form com= plexes with humic acid. Divalent cations are weakly complexed compared to $\mathrm{H}^{+}$, and their adsorption is not proportional to the concentra $=$ tion in the low $C_{s}$ range. This tendency will be explained that when the added metal ion forms complex with humic acid, the acid loses its charge and the dissociation of carboxyl group may be accelerated. The release of hydrogen 
ion greatly influences on conductivity and de= creases the metal complex formation. From Fig. -6 the order of complex forming ability of metal cations is determined;

$$
\mathrm{Na}^{+}, \mathrm{K}^{+} \ll \mathrm{Mg}^{2+}<\mathrm{Ca}^{2+}<\mathrm{Ba}^{2+} \ll \mathrm{Cu}^{2+}<\mathrm{H}^{+}
$$

As for Aldrich humic acid, the metal chela $=$ tion order is similar to that for marine humic acid. The high ability of Aldrich humic acid for complex formation is attributed to its high acidity. These results are, however, quite dif $=$ ferent from the sequence in the Irving-Williams series $^{4)}$.

\section{$3 \cdot 3 \cdot 2$ Potentiometric Titration}

Titration curves of potassium humate $(0.05 \mathrm{~g} / 100 \mathrm{ml})$ solution containing $\mathrm{M}^{n+} \mathrm{Cl}_{n}$ with $\mathrm{HCl}$ are shown in Fig.-7. The $\mathrm{pH}$ drop will be due to the flloowing reactions :

$$
\begin{aligned}
& -\mathrm{COOH}+\mathrm{M}^{+} \longrightarrow-\mathrm{COOM}+\mathrm{H}^{+} \\
& 2(-\mathrm{COOH})+\mathrm{M}^{2+} \\
& \longrightarrow(-\mathrm{COO}){ }_{2} \mathrm{M}+2 \mathrm{H}^{+}
\end{aligned}
$$

Here we consider for simplicity only car= boxyl group, but phenolic hydroxyl group has to be taken into account in the high $\mathrm{pH}$ range. Even without $\mathrm{HCl}$, the solution $\mathrm{pH}$ largely decreases with addition of metal cations.

From the figure, it is assumed that the stability constant of the complex can be

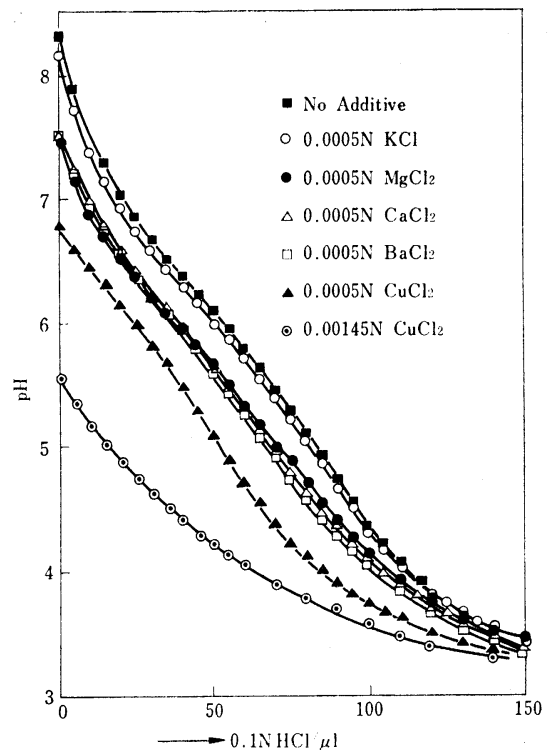

Fig.-7 Titration curves of marine humic acid with metal salts (humic acid con= centration : $0.05 \mathrm{~g} / 100 \mathrm{ml}$ ). estimated at about $\mathrm{pH}=5$. The sequence is as follows :

for marine humic acid,

$$
\mathrm{K}^{+} \ll \mathrm{Mg}^{2+}<\mathrm{Ca}^{2+}<\mathrm{Ba}^{2+}<\mathrm{Cu}^{2+}
$$

for Aldrich humic acid, $\mathrm{K}^{+} \ll \mathrm{Mg}^{2+} \ll \mathrm{Cu}^{2+}$ These orders are the same as those from con= ductivity measurements. Stevenson ${ }^{5)}$ reported that there was a close relationship between titratable $\mathrm{H}^{+}$and apparent total binding capacity for metal cations and that $\mathrm{COOH}$ groups play a prominent role in complex formation. The same is observed in our study.

\section{$3 \cdot 3 \cdot 3$ Viscosity}

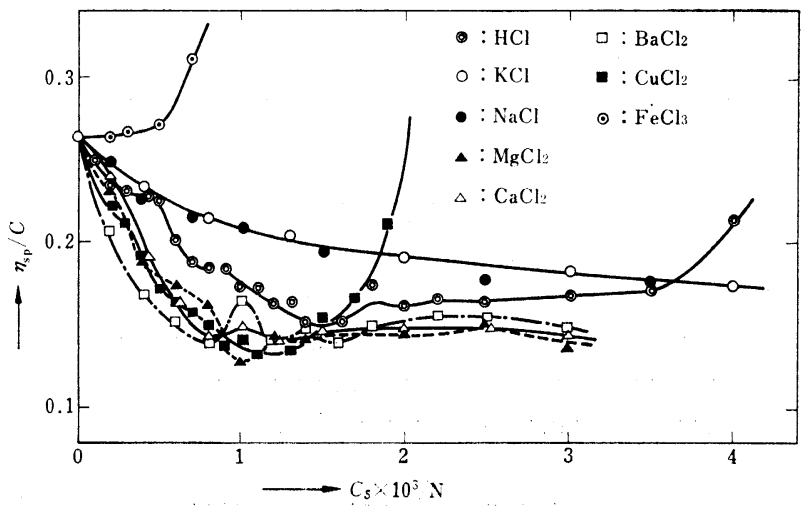

Fig.-8 Effect of metal ion on viscosity (marine humic acid : $0.05 \mathrm{~g} / 100 \mathrm{ml}$ ).

The viscosity changes of the potassium marine humate solution with addition of metal chlorides are shown in Fig.-8. The viscosity value de= creases with addition of $\mathrm{KCl}, \mathrm{NaCl}, \mathrm{HCl}$ and $\mathrm{M}^{2+} \mathrm{Cl}_{2}$; among them divalent ions are the most effective. The rise of viscosity value at $C_{s}=$ $1.5 \times 10^{-3} \mathrm{~N}$ may be due to the precipitate for $=$ mation caused by the neutralization of the charges of humic acid; in this case, carboxyl ion concentration is about $1.45 \times 10^{-3} \mathrm{~N}$. On the curve of $\mathrm{H}^{+}$, a hump is observed at $C_{s}=0.5 \times$ $10^{-3} \mathrm{~N}(\mathrm{pH}=6)$; the aggregation will occur at this $\mathrm{pH}$ in $0.05 \mathrm{~g} / 100 \mathrm{ml}$ soultion. The pre= cipitation begins at $1.5 \times 10^{-3} \mathrm{~N}$ in the system.

In the low $C_{s}$ region of divalent cations, the influence of aggregation on viscosity may be seen in the irregularity of curves and in the different sequence of complexing ability from the literature. At $C_{s}=1.5 \times 10^{-3} \mathrm{~N}$, the solu tion with $\mathrm{Mg}^{2+}, \mathrm{Ca}^{2+}, \mathrm{Cu}^{2+}, \mathrm{Ba}^{2+}$ and $\mathrm{H}^{+}$show almost the same viscosity value and these solue tions except $\mathrm{Cu}^{2+}$ change the value little in the 
more concentrated region. As for $\mathrm{Cu}^{2+}$, the viscosity rises according to the concentration increase and precipitate is formed at $C_{s}=2.5 \times$ $10^{-3} \mathrm{~N}$.

In the case of $\mathrm{Fe}^{3+}$, the viscosity increases with its concentration suggesting that the com= plexed polymer of humic acid with the metal ion may play an important role.

When metal ions chelate with the humic acid, two effects on the viscosity can be consi= dered; The decrease due to the contraction by intramolecular bonding and the increase due to the aggregation. To discuss the effect of intramolecular chelation, a dilute solution must be examined. But as the viscosity value of such solution is undetectably small, solutions neu= tralized in high degree were used to avoid the effect of aggregation. In the highly neutralized systems the low viscosity value continues in the high concentration range with $\mathrm{Ca}^{2+}$ and $\mathrm{Mg}^{2+}$, while $\mathrm{K}^{+}$shows high value. It is also examined by addition of $\mathrm{KCl}$ that the increase of ionic strength due to the addition of metal ions does not cause a viscosity drop.

\section{$3 \cdot 3 \cdot 4$ Interfacial Tension}

$3 \cdot 3 \cdot 4 \cdot 1$ Dependence of interfacial tension on $\mathrm{pH}$ The influence of $\mathrm{pH}$ change on the interfacial tension is shown in Fig.-9. The interfacial tension is low in the low $\mathrm{pH}$ range, indicating that the decrease of carboxyl ions makes humic acid less hydrophilic.

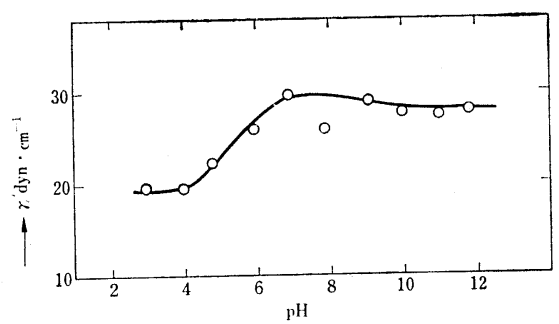

Fig.-9 pH dependence of interfacial tension (marine humic acid : $0.002 \mathrm{~g} / 100 \mathrm{ml}$, ionic strength $: 0.01 \mathrm{M}$ ).

3.3.4.2 Addition of metal ions The effect of metal ions on the interfacial tension is shown in Fig.-10. The values were measured $3 \mathrm{~d}$ after the interface preparation. Metal ions ex= cept $\mathrm{K}^{+}$and $\mathrm{Na}^{+}$lower the interfacial tension; the order is,

$$
\mathrm{K}^{+}, \mathrm{Na}^{+}<\mathrm{Mg}^{2+}<\mathrm{Ca}^{2+}<\mathrm{Ba}^{2+}<\mathrm{H}^{+}<\mathrm{Cu}^{2+}
$$

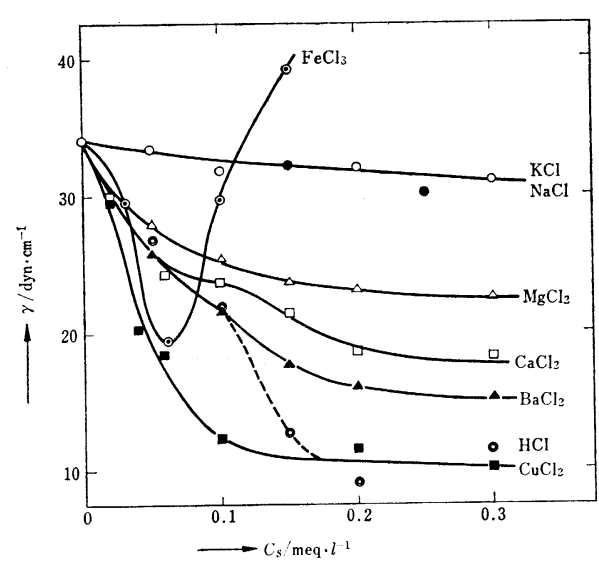

Fig.-10 Effect of metal ion on interfacial tension (marine humic acid : 0.002 $\mathrm{g} / 100 \mathrm{ml}$ ).

which is the same as that from conductivity measurements. It is assumed that the increase of the surface activity in the low $\mathrm{pH}$ range is caused by the decrease of the amount of car= boxyl ions, which is the case with the metal ion effect on the interfacial tension.

\section{$3 \cdot 3 \cdot 5$ Discussion}

It is well known that the humic acid forms complex with various metal ions ${ }^{6)}$. The orders of stability of metal humic acid complexes esti= mated by potentiometric titration, interfacial ten $=$ sion, viscosity and conductivity measurements are almost the same in this study. Though there exists considerable controversy in the lit= erature, our results are also different from the series published ${ }^{2)}$. Only the fact that $\mathrm{Cu}^{2+}$ forms one of a most stable complex is in accor $=$ dance with many other reports ${ }^{7}$.

In this paper we have described qualitative effects of metal ions on the solution properties of humic acids, the study of quantitative esti= mation is now in progress.

\subsection{Molecular Size Effect on the Solution Properties}

3.4.1 Sample characteristics

Elementary analysis data and acidity of the fractionated samples by ultrafiltration are listed in Table-1. The nitrogen content and acidity value increase according to the molecular size decrease. The fraction of the highest molecular weight occupies a half of the whole sample.

$3 \cdot 4 \cdot 2$ Viscosity

The viscosity of the fractionated sample solu= 
Table-1 Elementary analysis, optical density ratio, viscosity and acidity of fractionated samples.

\begin{tabular}{l|c|c|c|c|c|c|c|c}
\hline & wt.\% & $\mathrm{C}$ & $\mathrm{H}$ & $\mathrm{N}$ & $\mathrm{O}^{2)}$ & $E_{4} / E_{6}$ & {$[\eta]^{3)}$} & Acidity $^{4}$ \\
\hline Original & & 49.8 & 5.4 & 4.6 & 38.5 & 4.05 & 0.110 & 3.00 \\
\hline No. 1 & 49.0 & 51.6 & 5.7 & 4.1 & 33.6 & 3.73 & 0.126 & 3.04 \\
No. 2 & 14.9 & 53.6 & 5.9 & 5.1 & 32.2 & 3.87 & 0.083 & 2.97 \\
No. 3 & 16.0 & 52.0 & 4.8 & 5.5 & 34.4 & 3.96 & 0.047 & 3.82 \\
No. 4 & 20.1 & 51.6 & 4.4 & 7.4 & 33.5 & 4.96 & 0.030 & 4.95 \\
\hline Aldrich & & 50.9 & 4.1 & 1.0 & 41.9 & 8.10 & 0.025 & 5.18 \\
\hline
\end{tabular}

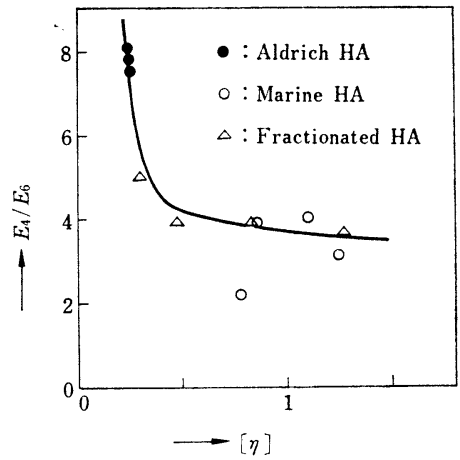

1) The sample was fractionated with 3 membranes and the resulted four samples were numbered from the highest mulecular weight to the lowest.

2) $100-(\mathrm{C}+\mathrm{H}+\mathrm{N})$

3) Values in $0.01 \mathrm{~N} \mathrm{KOH}$

4) In $0.02 \mathrm{M} \mathrm{KCl}$, value to $\mathrm{pH}=7.5$

tion in $0.01 \mathrm{~N} \mathrm{KOH}$ is shown in Fig. $-11 . \mathrm{Ap}=$ parently, the viscosity shows a value in order of melecular weight; the larger molecule gives the higher viscosity value. From the figure, the aggregate formation is indicated for the fractionated samples.

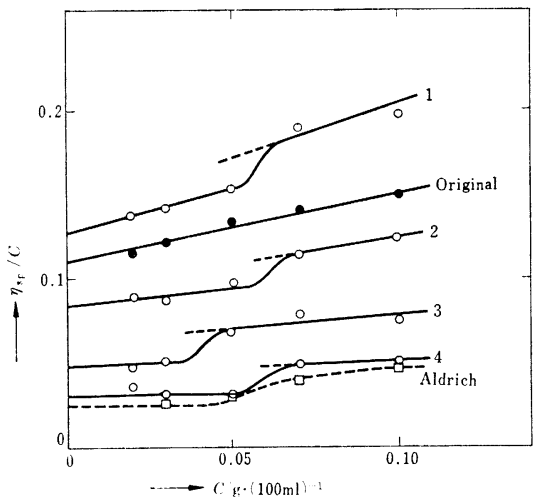

Fig.-11 Viscosity of fractionated samples.

\section{$3 \cdot 4 \cdot 3$ Other properties}

The samples exhibit the same absorption spectra in visible region. At about $405 \mathrm{~nm}$, a small peak appears and then the absorbance decreases monotonously as the wave length increases.

The ratio of optical densities of humic acid solution at 465 and $665 \mathrm{~nm}$ is used for the es= timation of the degree of humification ${ }^{8}$, which is usually referred to as $E_{4} / E_{6}$. The relation of viscosity-acidity and viscosity-optical density are shown in Fig. -12 . The tendency that the large $E_{4} / E_{6}$ ratio corresponds to the large molecular

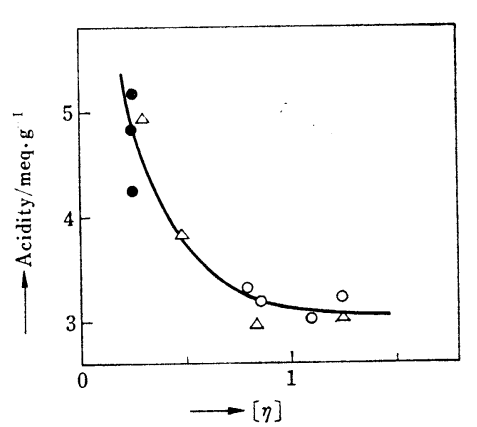

Fig. 12 Relation between acidity, $E_{4} / E_{6}$ and viscosity.

size is observed. The large molecule has low acidity value is also confirmed.

(Received Sept. 16, 1983)

\section{References}

1) S. Hayano, N. Shinozuka, and O. Shinji, Yuu kagaku, 32, 10 (1983).

2) S. Hayano, N. Shinozuka, and M. Hyakutake, Yukagaku, 31, 357 (1982).

3) D. Attwood and S.P. Agarwal, J. Chem. Soc. Faraday I, 76, 570 (1980).

4) H. Irving and R.P.J. Williams, Nature, 162, 746 (1948).

5) F. Stevenson, Soil Sci. Soc. Am. J., 40, 665 (1976).

6) M. Schnitzer and S.U. Khan, "Humic Sub= stances in the Environment" Marcel Dekker, Inc., New York (1972), p. 203 ; R.F.C. Man= toura, "Marine Organic Chemistry" Elsevier Scientific Publishing Co., Amsterdam (1981), p. 179 .

7) H. Van Dijk, Geoderma, 5, 53 (1971); A. Piccolo and F.J. Stevenson, Geoderma, 27, 195 (1982) ; S, Hirata, Talanta, 28, 809 (1981).

8) M.M. Kononova, "Soil organic Matter", Per= gamon Press, Oxford (1966) p. 544. 
海洋フミン酸の溶液的性質 (II)

会合体形成及び溶液的性質への

金属イオンの影響

篠塚則子・新治 修* ・早野茂夫

東京大学生产技術研究所 (東京都港区六本木 7-22-1)

* 現勤務先 : 昭和電線 (株)

フミン酸溶液の界面張力及び導伝率を測定し，その結 果, 会合体の生成が示唆された。会合が始まる濃度は他 の方法で決定した濃度と良く一致した。 金属カチオンのフミン酸溶液の導伝率, 粘度, 界面張
力, 電位差滴定への影響も調べた。添加した金属カチ才 ンは海洋フミン酸と錯体を形成する。金属イオンの錯形 成能の順序は次の通りである。

$$
\mathrm{Na}^{+}, \mathrm{K}^{+}<\mathrm{Mg}^{2+}<\mathrm{Ca}^{2+}<\mathrm{Ba}^{2+}<\mathrm{Cu}^{2+}
$$

金属イオンは主としてフミン酸のカルボキシル基と結 合するものと思われる。溶液的性質に及ぼすカチオンの 影響については, 海洋フミン酸と市販の Aldrich フミ ン酸の間には本質的な差は観察されなかった。

分子量分画した海洋フミン酸試料を用いて, 溶液的性 質に対する分子の大きさの影響について調べた。より小 さい分子はより低いフミン化度と, より高い酸度を示す ことが確かめられた。 